\title{
Consequences of parental corporal punishment on 12-year old children in the Colombo district
}

\author{
Piyanjali de Zoysa ${ }^{1}$, Peter A Newcombe ${ }^{2}$ and Lalini Rajapakse ${ }^{3}$
}

\begin{abstract}
Objective To study the association between parental corporal punishment and psychological maladjustment in children. Potential mediating variables of this association were explored. The relationship between corporal punishment and physical abuse was also investigated.
\end{abstract}

Design, setting and sample The children $(\mathrm{N}=1226,12-$ year olds) were selected from government schools in the Colombo district, using a stratified random sampling technique.

Measurements Self-administered instruments, adapted and validated to the Sri Lankan context were used.

Results The experience of parental corporal punishment was shown to be moderately, but significantly, associated with psychological maladjustment in children. This association was enhanced by the child witnessing or experiencing non-parent-to-child violence (eg. domestic, community, teacher and peer violence). The extent of the child's support network, the nature of the parent-child relationship and the child's attitude to corporal punishment did not significantly alter the association between corporal punishment and psychological maladjustment. Corporal punishment was also moderately, but significantly, associated with child physical abuse.

Conclusions Parental corporal punishment is associated with psychological harm for children; this association is further enhanced by other forms of violence in a child's life.

\section{Introduction}

Disciplining children is a key aspect of parenting. There is currently much interest on what constitute healthy and unhealthy disciplinary methods, especially with regard to corporal punishment [1]. Corporal punishment is the use of physical force with the intention of causing a child to experience pain but not injury for purposes of correction or control of the child's behaviour [2]. Physical abuse, on the other hand, is characterised by the infliction of physical injury as a result of punching, beating, kicking, biting, burning, shaking or otherwise harming a child. In physical abuse, the parent may not have intended to hurt the child, rather the injury may have resulted from severe corporal punishment [3]. Some tend to view corporal punishment and physical abuse along a continuum, so that, when corporal punishment is administered too severely or frequently the outcome can be abuse $[3,4]$.

The merits and demerits of corporal punishment have been argued for decades [4]. Some have concluded that it is effective if used within certain conditions [5], others have concluded that it is ineffective at best and harmful at worst [6]. Although corporal punishment is associated with the short term suppression of undesired behaviour [7], it may not lead to long term compliance [8] or internalisation of the parental disciplinary message [9]. Corporal punishment has also been associated with a number of short and long term negative psychological outcomes in children $[10,11,12,13]$. Aside from these adverse outcomes, corporal punishment used with increasing frequency and severity has been shown to lead to physical abuse [14].

The association between parental corporal punishment and psychological maladjustment appears to be influenced by various factors in a child's life. For instance, the experience of corporal punishment is associated with the child witnessing domestic and community violence [15], and being victimised in the school [16], such as by teachers or peers. The child's support network may alter the negative psychological effect of such punishment $[4,17,18]$. Similarly, corporal punishment used by a nurturant parent appears to buffer its negative psychological outcomes [19]. Corporal punishment used in a consistent manner [20], a child's perceived fairness of the use of corporal punishment [21], and parent-child dialogue when using such punishment [5] has also been considered to ameliorate its negative outcomes.

\section{Method}

A sample of 1226 (60.8\% girls) 12-year olds was chosen by a stratified random sampling technique from all Sinhala language government schools in the Colombo

Departments of ${ }^{1}$ Psychological Medicine, and ${ }^{3}$ Community Medicine, Faculty of Medicine, University of Colombo, Kynsey Road, Colombo 8; and 'School of Social Work and Applied Human Sciences, School of Psychology, Faculty of Social and Behavioural Sciences, University of Queensland, Brisbane, Australia 4072.

Correspondence: PdeZ, Telephone (mobile 0777878 383; +94 112695300 office). Received 21 May, and revised version accepted 31 October 2007. Conflicts of interest: none declared. This study was supported by a grant from the Save the Children Fund, UK and Norway. 
district. Buddhists were a majority $84.8 \% ; 6.4 \%$ were Islam, 4.1\% Roman Catholic, 3.4\% Christian, and 1.2\% Hindu and $90.2 \%$ were of Sinhalese ethnic origin (1.8\% Moslem; 2.4\% Sri Lankan Tamil; 0.6\% Malay; 0.6\% Burgher; 0.4\% Indian Tamil; $0.1 \%$ Other). Permission for the study was obtained from the appropriate Ministry and approval was obtained from the ethical review committee of the Faculty of Medicine, Colombo. Verbal consent to take part in the study was obtained.

The minor physical assault (ie. corporal punishment) scale of the Parent-Child Conflict Tactics Scale's Sinhala version [CTSPC: 22] was used to determine corporal punishment. CTSPC scales of severe and very severe assault were used to measure physical abuse [22]. The Personality Assessment Questionnaire's Sinhala version [PAQ: 22] was used to determine psychological maladjustment in the children. The Psychosocial Questionnaire [PSQ: 22] comprised of items shown in previous research to be associated with parental use of physical force and its outcomes. The PSQ has four indicators of non-parent-to-child violence (eg. domestic, community, peer, and teacher), two indicators of a child's support network (peer and adult), four indicators of the parent-child relationship (nurturance, consistency in using corporal punishment, children's perceived fairness of parental corporal punishment, and parent-child dialogue when using corporal punishment), and one indicator of child's attitude to corporal punishment.

The instruments were administered to all 12-year olds who attended class on the test day. Children were informed of the nature of the study and that confidentiality of answers would be maintained. The first author administered the instruments and was available throughout to clarify any doubts.

\section{Results}

Structural equation modelling [SEM] a statistical technique that analyses complex relationships among study variables, was used to analyse the data [22].

Results showed that increasing levels of corporal punishment was moderately, but significantly, associated with a child's psychological maladjustment. This association was significantly enhanced by the extent of the child's experience of non-parent-to-child violence. The extent of the child's support system, the nature of the parent-child relationship and child's attitude to corporal punishment did not significantly alter the corporal punishment psychological maladjustment association [23]. There was a moderate, yet significant, association between corporal punishment and child physical abuse [22].

\section{Discussion}

Our study showed that increasing levels of corporal punishment were significantly associated with a child's psychological maladjustment, a finding corroborated by previous research $[10,11,12,13]$, and that the experience of non-parent-to-child violence is directly related to corporal punishment. Non-parent-to-child violence leads to further psychological maladjustment in children. The experience of corporal punishment and its association with children experiencing or witnessing other forms of violence has been corroborated by previous research [15]. Parents who are violent towards their spouse have a greater tendency to use physical force when their children misbehave [15]. Being a recipient or witness of family or community violence is associated with several psychological problems in the child [4], which may lead to a deficit in their coping skills. These psychological problems and deficits in coping skills may make the child vulnerable to further victimisation in non-family situations, such as in school, by teachers or peers [16], a vicious cycle of violence and psychological problems for the child.

Our results showed too that a child's favourable attitude to corporal punishment was associated with experience of such discipline - a finding corroborated by previous research [23], but such a favourable attitude did not have a significant buffering effect on the association between corporal punishment and psychological maladjustment. These findings indicate that corporal punishment is associated with psychological harm, despite a child's favourable attitude towards such discipline.

We found that the nature of parent-child relationship does not have a significant buffering effect on the negative psychological outcome of corporal punishment. Hence, even though a child may perceive the parents as warm and loving, if the parents use corporal punishment, it may be associated with psychological maladjustment. Even if parents used corporal punishment with consistency, fairness and dialogue, that did not appear to buffer corporal punishment's negative psychological outcome. Although previous research has shown that a healthy support system buffers the negative psychological outcomes of corporal punishment [18], this was not confirmed in our study [23], the reasons for which need to be explored in future research.

We also noted that children report the experience of physical abuse in direct proportion to corporal punishment experienced by them. Corporal punishment appears to be a risk factor for child physical abuse.

These findings have implications for educating Sri Lankan parents on child rearing in general and corporal punishment in particular. Most Sri Lankans accept corporal punishment as useful and preventing its use is considered as imposing "western" ideas in Sri Lanka [22]. Historical records however indicate that in ancient Sri Lanka, corporal punishment of children may have been prohibited by some of its kings [25].

\section{References}

1. Parke RD. Punishment revisited - science values and the 
right question: Comment on Gershoff, 2002. Psychological Bulletin 2002; 128: 596-601.

2. Straus MA. Beating the devil out of them: Corporal punishment in American Families. San Francisco: JosseyBass/Lexington Books, 1994: 24-72.

3. National Clearinghouse on Child Abuse and Neglect Information. What is child maltreatment. Viewed 2 July 2001, <http://www.calib.com/nccanch/prbs/factsheets/ childmal. Cfm>, 2001a.

4. Gershoff ET. Corporal Punishment by parents and associated child behaviors and experiences: A macro-analysis and theoretical review. Psychological Bulletin 2002, 128: $539-79$.

5. Larzelere RE. Child outcomes of non abusive and customary physical punishment by parents: An updated literature review. Clinical Child and Family Psychology Review 2000, 3: $199-221$.

6. American Academy of Pediatrics. Guidance for effective discipline. Pediatrics 1998, 101: 723-28.

7. Straus MA. Demystifying the defenses of corporal punishment. In: Straus MA; ed. The primordial violence: Corporal punishment by parents, cognitive development, and crime. Walnut Creek, CA: Alta Mira Press, 2003: 19-33.

8. Lepper MR. Social control processes and the internalisation of social values: An attributional perspective. In: Higgins ET, Ruble DN Hartup WW; eds. Social cognition and social development. 9th ed. New York: Cambridge University Press, 1983: 294-300.

9. Grusec JE. The internalization of altruistic dispositions: A cognitive analysis. In: Higgins ET, Ruble DN, Hartrup WW; eds. Social cognition and social development. 9th ed. New York: Cambridge University Press, 1983: 275-93.

10. Straus MA. Corporal punishment of children and adult depression and suicidal ideation. In: MacCord J; ed. Coercion and punishment in long term perspective. New York: Cambridge University Press, 2000: 92-114.

11. Cohen P, Brook JS, Cohen J, Velez N, Garcia M. Common and uncommon pathways to adolescent psychopathology and problem behavior. In: Robins L, Rutter, M; eds. Straight and devious pathways from childhood to adulthood. Cambridge: Cambridge University Press, 1990: 242-58.

12. Straus MA, Sugarman DB, Giles-Sims J. Spanking by parents and subsequent antisocial behavior of children. Archives of Pediatric and Adolescent Medicine 1997; 15: 761-67.

13. Swinford SP, De Maris A, Cernkovich SA, Giardano PC. Harsh physical discipline in childhood and violence in later romantic involvements: The mediating role of problem behaviors. Journal of Marriage and the Family 2000; 62: 508-19.

14. Durrant JE, Rose-Krasnor L. Corporal punishment. Research review and policy recommendations. Canada: The Family Violence Prevention Division of Health Canada and the Department of Justice Canada, 1995: 7-9.

15. Kim D, Kim K, Park Y, Zhang LD, Lu MK. Children's experience of violence in China and Korea: A trans-cultural study. Child Abuse and Neglect 2000; 24: 1163-73.

16. Hughes HM. Psychosocial and behavioral correlates of family violence in child witnesses and victims. American Journal of Orthopsychiatry 1998; 58: 77-90.

17. Mason CA, Cauce AM, Gonzales N, Hiraga Y. Neither too sweet nor too sour: Problem peers, maternal control, and problem behavior in African American adolescents. Thousand Oakes, CA: Sage, 1996: 111-32.

18. Milner JS, Robertson KR, Rogers DC. Childhood history of abuse and adult child abuse potential. Journal of Family Violence 1990; 3: 15-34.

19. Deater-Deckard K, Dodge KA. Externalizing behavior problems and discipline revisited: Nonlinear effects and variation by culture, context, and gender. Psychological Inquiry 1997; 8: 161-75.

20. Simons RL, Whitbeck LB, Melby JN, Wu C. Economic pressure and harsh parenting. In: Conger RD, Elder Jr. GH; eds. Families in troubled times: Adapting to change in rural America. New York: Aldine de Gruyter, 1994: 207-22.

21. Rohner RP, Bourque SL, Elordi CA. Childrens' perceptions of corporal punishment, caretaker acceptance, and psychological adjustment in a poor, biracial southern community. Journal of Marriage and the Family 1996, 58: $842-52$.

22. De Zoysa P. Parental use of physical force towards school children in the Colombo district: Prevalence, psychosocial correlates and psychological consequences. Doctoral dissertation: University of Colombo, Sri Lanka, 2006: 16091.

23. De Zoysa P, Newcombe PA, Rajapakse L. Corporal punishment in the Sri Lankan context: psychological outcomes for our children. In: Devore DM; ed. New developments in parent-child relations. New York: Nova Science Publishers, Inc, In press.

24. Dietz TL. Disciplining children: characteristics associated with the use of corporal punishment. Child Abuse and Neglect 2000; 24: 1529-42.

25. Moldrich D. Somewhere a child is crying. Colombo: Ceylon Printers Ltd, 1986: 15-26. 